\title{
MINERALOGICAL AND GEOCHEMICAL STUDY OF THE KIRKI MINING WASTES, EVROS REGION, GREECE - DETERMINATION OF THE ENVIRONMENTAL IMPACT BY TOXIC AND HEAVY METALS
}

\author{
Arikas K. \\ ${ }^{1}$ Mineralogisch-Petrographisches Institut, Universität Hamburg, Grindelallee 48, 20146 \\ Hamburg Germany,mi9a004@mineralogie.uni-hamburg.de
}

\begin{abstract}
Mining activity at the Kirki ore deposit has occurred over short periods, from 1974 to1980 and 1990 to 1997. The mining wastes at the cracked tailing ponds and at other on-site locations of the plant, together with the remains of the mining concentrates, the piles of the unprocessed ore and the large number of destroyed and weathered barrels of chemical reagents, including sodium cyanide, are a great risk to public health. All these wastes are exposed to rain-water and constitute a permanent source of toxic metals and other materials, which are transported by the adjacent small river of Erini, contaminating the hydrologic system of the whole area including the city of Alexandroupolis. For example, the concentrations of toxic metals such as $\mathrm{Pb}, \mathrm{Cu}, \mathrm{Zn}, \mathrm{As}$ and $\mathrm{Cd}$ in the clay fraction of the river sediments is 2100, 300, 50, 100 and 660 times, respectively, above the natural background concentrations.
\end{abstract}

Key words: Acid drainage, soil contamination, metal-bearing wastes.

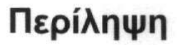

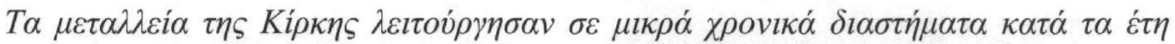

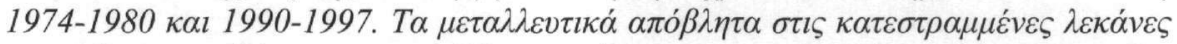

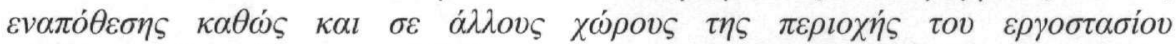

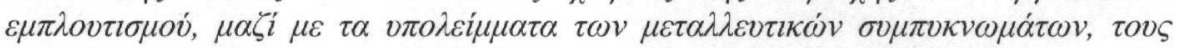

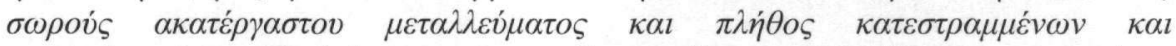

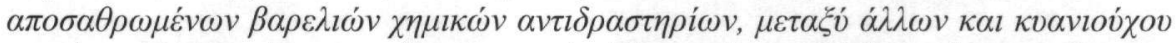

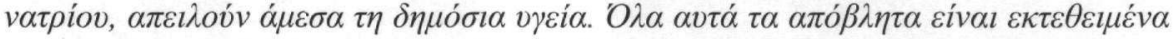

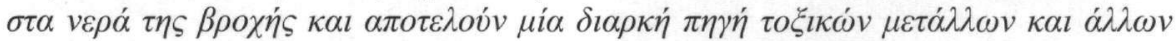

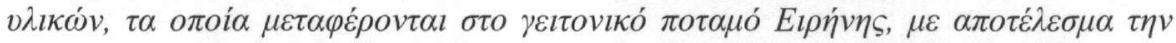

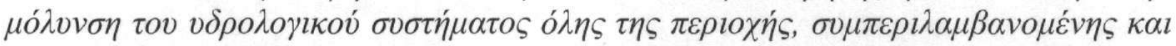

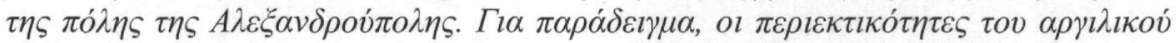

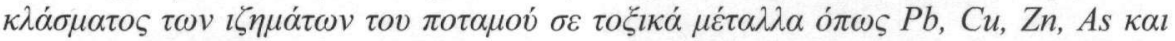

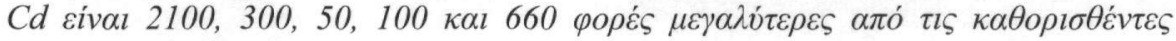

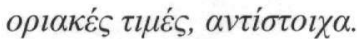

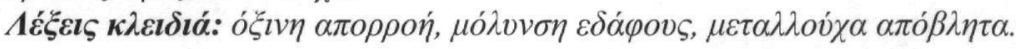




\section{Introduction}

Mining has been a very important economic activity in Northern Greece since antiquity, due to the significant metal-rich ore deposits which occur within the different geological environments of the area. The result of this activity is significant environmental pollution, since mining is one of the major sources of toxic and heavy metal contamination (Kelepertsis and Bibou 1991, Astaras et al. 1997, Darlagiannis et al. 2002, Kitsopoulos and Pavlidou 2004, Karatasou et al. 2005, Damigos and Kaliampakos 2006, among others).

The case study of the Kirki ore-district pollution has been previously published by Watzl (1998), Finitsi et al. (2002), Arikas et al. (2004), Skarpelis and Triantafyllidis (2004), and Asfahani et al. (2005). The mixed-sulfides mine of Saint Philippos in Kirki, located $6 \mathrm{~km}$ to the northeast, and particularly the flotation plant, located $3 \mathrm{~km}$ east of Kirki (Fig. 1), have caused great environmental damage during the relatively short operation periods of 1974-80 and 1990-97. The mining wastes at the cracked tailing ponds (Fig. 1) and at other locations of the plant, the remains of the mining concentrates, the piles of the unprocessed ore and the large number of destroyed and weathered barrels with chemical reagents, including sodium cyanide, are a great risk to public health. All these wastes are exposed to rain-water and constitute a permanent source of toxic metals and other materials, which are transported via the adjacent small river of Erini which flows to the south, and which discharges $23 \mathrm{~km}$ downgradient into the Thracean Sea, east of the city of Alexandroupolis (Fig.1).

Poor management during the past mining and mineral processing has led to a significant environmental loading of the region with toxic leachate and toxic metals, such as $\mathrm{Pb}, \mathrm{Zn}, \mathrm{Cu}, \mathrm{As}$, $\mathrm{Cd}$ and others. The oxidation and the erosion of the sulfides within the tailing ponds and from the mineral concentrates has lead to the formation of new sulfate minerals, increasing the acid drainage and the emission of toxic metals into the hydrologic system (Arikas et al. 2004).
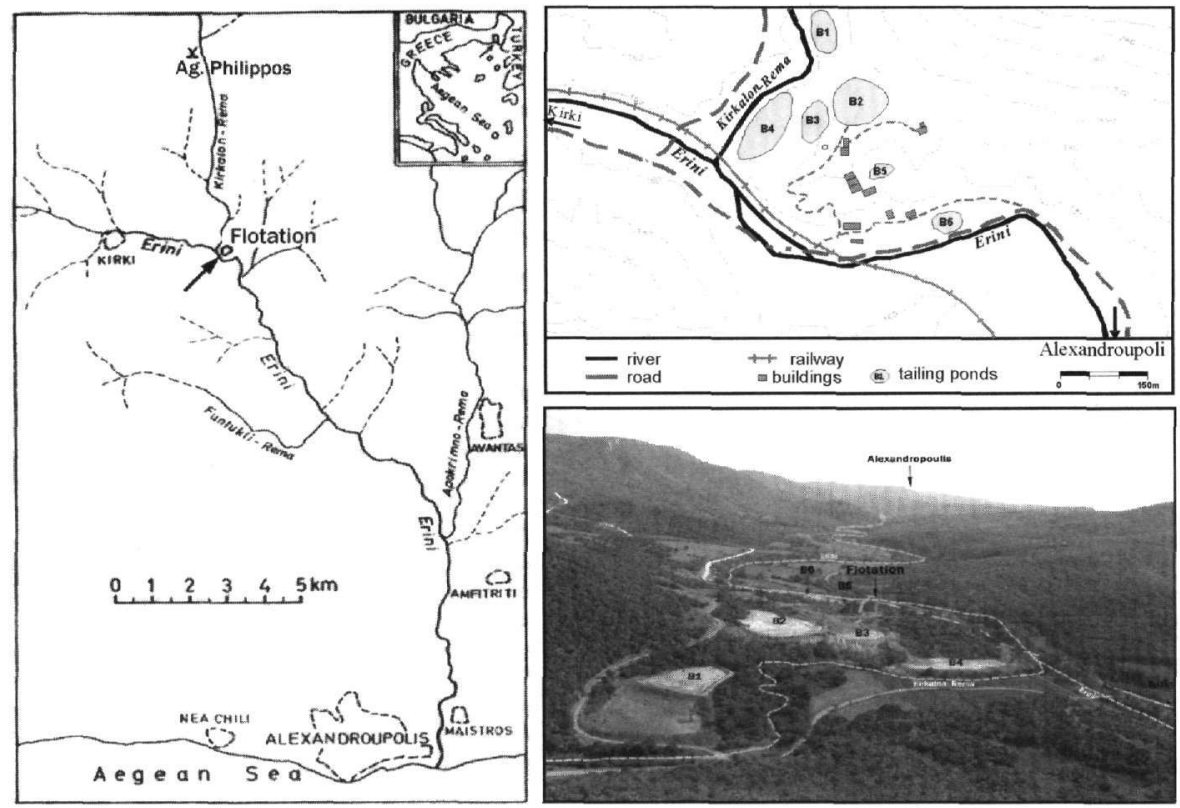

Figure 1 - Sketch maps and a figure of the studied area. Left figure: Sketch of the drainage pattern of the Erini River and the area around Kirki, the Saint Philippos mine and Alexandroupolis. At the right side (top) the detail of the flotation plant and the tailing ponds are shown. Right side (bottom): Panoramic view of the flotation plant. B1-B6: tailing ponds. The dashed lines show the rivers of Kirkalon and Erini. (Picture taken from the Tigris Hill from the northwest) 
This study presents new mineralogical and geochemical data of three exceptionally polluted districts near Kirki in the region of Evros, which are 1) the tailing ponds and ore mineral concentrates, 2) the soils around the plant area and 3) the sediments of the Erini River, in order to determine the concentrations of the various heavy and toxic metals and the related minerals which carry such metals.

\section{Analytical Techniques}

Sampling was carried out during the years 1998 to 2005 . The mineralogical and geochemical studies include: 1) the tailing ponds and ore mineral concentrates, 2) the area around the plant and 3 ) the sediments of the Erini River. Special care was assigned in the sampling of the six tailing ponds, where $80 \mathrm{~cm}$ deep sections were dug and a total of 29 samples were obtained (3 to 9 samples per section). In pond B4 the section was $110 \mathrm{~cm}$ deep, due to the erosion by rain water. Additional sampling was carried at the surface $(2 \mathrm{~cm}$ deep) of the ponds where whitish finegrained secondary minerals have been formed.

Clay minerals in the selected samples were identified by X-ray diffraction (XRD) analysis of wholerock samples and clay fractions $(<65 \mu \mathrm{m})$ at the University of Hamburg. The geochemical study is based on a total of 180 chemical analyses for major and trace elements, measured with Inductively Coupled Plasma Atomic Emission Spectrometry (ICP-AES), Total Reflection X-Ray Fluorescence (TXRF) and Atomic Absorption Spectrometry (AAS) at the University of Hamburg. The results focus on the following heavy metals: $\mathrm{Fe}, \mathrm{Mn}, \mathrm{Pb}, \mathrm{Zn}, \mathrm{Cu}$, $\mathrm{As}$ and $\mathrm{Cd}$, which are present in the mined and processed ore.

\section{Geological setting}

The geology of the studied area is dominated by Oligocene synorogenic subvolcanic stocks and dikes of calc-alkaline to high-K calc-/alkaline affinity. The magmatism resulted from the underthrusting of the African plate beneath the southern margin of the Eurasian plate and is attributed to slab break-off and/or slab delamination mechanisms (De Boorder et al. 1998, Christofides et al. 1998). A basal-clastic formation of Middle to Upper Eocene age including tuffaceous material (Papadopoulos 1982) discordantly covers the high to ultra-high grade metamorphic basement of the Rhodope massif (Mposkos and Kostopoulos 2001). A volcanic sequence consisting of lava domes, flows and pyroclastics of andesitic to dacitic composition was intruded at about $32 \mathrm{Ma}$ (Del Moro et al. 1988) by I-type subvolcanic dacite-andesitic and monzodioritic bodies. All the above lithologies are cut by rhyolitic dikes, which were intruded mainly along NNW-SSE trending faults.

The hydrothermal Pb-Zn deposit of Agios Philippos, north of Kirki (Fig. 1), NE-Greece, occurs as fracture fillings and breccia-hosted sulfides and sulfosalts in a tectonic zone bounded by two premineral subvertical faults (Michael et al. 1989, Dimou 1994, Skarpelis 1999, Voudouris et al. 2005). Rhyolites, which predate the mineralization, intruded the volcano-sedimentary host lithology. An advanced argillic alteration with alunite and minor pyrophyllite followed an early pervasive grey silicification of the rocks. Propylitic and sericitic hydrothermal alteration zones are developed peripheral to the ore zone. A part of the deposit comprises hydrothermal breccias of previously silicified sedimentary rock and rhyolite.

Exploration for $\mathrm{Pb}$ and $\mathrm{Ag}$ ores in the area of Kirki began late in the $19^{\text {th }}$ century. In 1932 English mining companies invested in exploration projects, started construction of mine shafts and managed to exploit 20,000 tn of ore. With the onset of the World War II, the German company "Thrazische Bergwerke" continued exploration in the Agios Philippos area. Small scale exploitation commenced and a part of a flotation plant with an $80 \mathrm{tn} /$ day capacity was installed. Exploration for base metals and $\mathrm{Ag}$ in the following years was carried out by several state owned Greek agents. In 1973 the lease was sublet to "Evros Mining Co" between 1974 and 1980 
(underground since 1977), which exploited and processed roughly 160,000 th of ore at 4 to $10 \%$ combined $\mathrm{Pb}$ and $\mathrm{Zn}$. $\mathrm{Pb}$ concentrates at $60-70 \% \mathrm{~Pb}, 3-7 \% \mathrm{Cu}$ and $500 \mathrm{gr} / \mathrm{tn} \mathrm{Ag}$, and $\mathrm{Zn}$ concentrates at $48-54 \% \mathrm{Zn}$ and $0.4-0.5 \% \mathrm{Cd}$ were produced. With several long interruptions, open pit mining and processing of the ore continued from 1990 up to 1997 and possibly 50,00070,000 tn of ore were extracted.

On the basis of mineralogical studies (Moëlo et al. 1985, Vavelidis et al. 1989, Michailidis et al. 1989, Dimou 1994, Skarpelis 1999, Voudouris et al. 2005) the following mineral composition has been determined: pyrite $\left(\mathrm{FeS}_{2}\right)$, sphalerite $(\mathrm{ZnS})$, wurtzite $(\mathrm{ZnS})$, galena $(\mathrm{PbS})$, jordanite $\left(\mathrm{Pb}_{14} \mathrm{As}_{6} \mathrm{~S}_{23}\right)$, Bi-jordanite $\left(\mathrm{Pb}_{14} \mathrm{BiAs}_{5} \mathrm{~S}_{23}\right)$, kirkiite $\left(\mathrm{Pb}_{10} \mathrm{Bi}_{3} \mathrm{As}_{3} \mathrm{~S}_{19}\right)$, cosalite $\left(\mathrm{PbBi}_{2} \mathrm{~S}_{5}\right)$, tennantite $\left(\mathrm{Cu}_{12} \mathrm{As}_{4} \mathrm{~S}_{13}\right)$, chalcopyrite $\left(\mathrm{CuFeS}_{2}\right)$, marcasite $\left(\mathrm{FeS}_{2}\right)$, bismuthinite $\left(\mathrm{Bi}_{2} \mathrm{~S}_{3}\right)$, kesterite $\left(\mathrm{Cu}_{2} \mathrm{ZnSnS}_{4}\right)$, luzonite $\left(\mathrm{Cu}_{3} \mathrm{SbS}_{4}\right)$, stibioluzonite (famatinite- $\left.\mathrm{Cu}_{3} \mathrm{SbS}_{4}\right)$, enargite-stibioenargite $\left(\mathrm{Cu}_{3}(\mathrm{As}, \mathrm{Sb}) \mathrm{S}_{4}\right)$, seligmannite $\left(\mathrm{CuPbAsS}_{3}\right)$, bournonite $\left(\mathrm{CuPbSbS}_{3}\right), \quad$ levyclaudite $\left(\mathrm{Pb}_{8} \mathrm{Sn}_{7} \mathrm{Cu}_{3}(\mathrm{Bi}, \mathrm{Sb})_{3} \mathrm{~S}_{28}\right)$, arsenopyrite $(\mathrm{FeAsS})$, stannite $\left(\mathrm{Cu}_{2} \mathrm{FeSnS}_{4}\right)$, bornite $\left(\mathrm{Cu}_{5} \mathrm{FeS}_{4}\right)$, and covellite (CuS). Quartz, kaolinite/dickite, alunite and barite are the gangue minerals closely associated with the ore. Massive wurtzite aggregates fill open spaces either of the ore or the silicified rocks, usually filling the inner wall of cavities. It is evident that wurtzite was the last formed sulfide mineral. Electron microprobe analysis from Driesner and Pintea (1994) revealed interesting trace element contents in wurtzite from Kirki: the $\mathrm{Fe}$ - and $\mathrm{Mn}$-content is below detection limit, $\mathrm{Cd}$ reaches up to $2.6 \mathrm{wt} \%$, In up to $3.5 \mathrm{wt} \%, \mathrm{Ga} 1.6 \mathrm{wt} \%$ and $\mathrm{Ge}<0.3 \mathrm{wt} \%$, while $\mathrm{Hg}$, Sn and Ag usually are below detection limit.

Euhedral to subhedral barite crystals accompany sulfides and sulfosalts throughout the ore zone. Calcite, dolomite and rarely rhodochrosite are found in veins and veinlets crosscutting the ore, especially in the deeper parts of the mineralized zone, indicating they were the late formed hydrothermal minerals.

\section{Results}

\subsection{The tailing ponds and mineral concentrates}

The mineralogical study of the six tailing ponds (Figs 1,2) which occur close to the flotation plant, revealed the presence of the typical hydrothermal-alteration minerals such as quartz, kaolinite, pyrophyllite, gypsum and sericite, as well as the most common ore minerals of the deposit, pyrite, galena and sphalerite/wurtzite.

In addition, the whitish fine grained secondary minerals (Fig. 2) formed at the sides of the tailing ponds due to the erosion of the mining wastes and the mineral concentrates, are considered to be of great importance for the environmental loading of the area. These minerals consist mainly of two various secondary sulfate salts: a halotrichite-dietrichite group-( $\mathrm{Fe}, \mathrm{Mn}, \mathrm{Zn}, \ldots) \mathrm{Al}_{2}\left(\mathrm{SO}_{4}\right) 4.22 \mathrm{H}_{2} \mathrm{O}$ and a rozenite-boyleite group- $(\mathrm{Zn}, \mathrm{Fe}, \mathrm{Mn}, \ldots)\left(\mathrm{SO}_{4}\right) \cdot 4 \mathrm{H}_{2} \mathrm{O}$. Both mineral groups area characterized by absorbing high concentrations of $\mathrm{Mn}, \mathrm{Fe}, \mathrm{Pb}, \mathrm{Cu}$ and mainly $\mathrm{S}, \mathrm{Zn}$ and $\mathrm{Cd}$, and as they are water soluble, they play a major role in the release of these metals into the environment and into the hydrologic system. Surface samples of pure whitish fine grained secondary minerals, mainly halotrichite and rozenite, contain up to $327,070 \mathrm{ppm} \mathrm{S}, 189,360 \mathrm{ppm} \mathrm{Zn}$ and 2,250 ppm Cd. In addition, due to their high sulfur content, they increase the acid drainage of the whole area. Wholerock chemical analyses (Table 1) of the surface samples of the tailing ponds containing these salt sulfates, showed extremely high concentrations in heavy metals such as $\mathrm{Pb}$ up to $12,620(51,450)$ ppm, $\mathrm{Cu}$ up to $1,310(5,750) \mathrm{ppm}, \mathrm{Zn}$ up to $57,830 \mathrm{ppm}$, As up to $490(1,185) \mathrm{ppm}$ and $\mathrm{Cd}$ up to $1,070 \mathrm{ppm}$.

The chemical analyses of the tailing ponds (Table 1) revealed up to $14,600 \mathrm{ppm} \mathrm{Pb}, 22,740 \mathrm{ppm}$ $\mathrm{Zn}, 3,900 \mathrm{ppm} \mathrm{Cu}, 944 \mathrm{ppm}$ As and $193 \mathrm{ppm} \mathrm{Cd}$. These results confirm the suggestion that the enrichment processing of the ore mineralization was insufficient which led to the loss of significant quantities of ore, which has been transported and has accumulated in the tailing ponds. 
Great piles of mineral concentrates remained inside and around the plant. Chemical analyses from the 8 concentrate piles are listed in table 2 . The main ore minerals identified here are pyrite, galena and sphalerite/wurtzite. Some ore has been oxidized and secondary minerals such as goethite and anglesite also occur. Hydrous salt sulfates are also found and the most widespread is rozeniteboyleite. The chemical analyses of the concentrates (Table 2) revealed up to $37,680 \mathrm{ppm} \mathrm{Pb}$, $188,740 \mathrm{ppm} \mathrm{Zn,} \mathrm{17,650} \mathrm{ppm} \mathrm{Cu,} \mathrm{5,240} \mathrm{ppm} \mathrm{As} \mathrm{and} \mathrm{1,350} \mathrm{ppm} \mathrm{Cd..} \mathrm{Samples} \mathrm{rich} \mathrm{in} \mathrm{sulfate} \mathrm{salts}$ from the eroded surface of the concentrate piles contain up to $254,850 \mathrm{ppm} \mathrm{Zn}$ and $2,560 \mathrm{Cd}$. (Table 2).
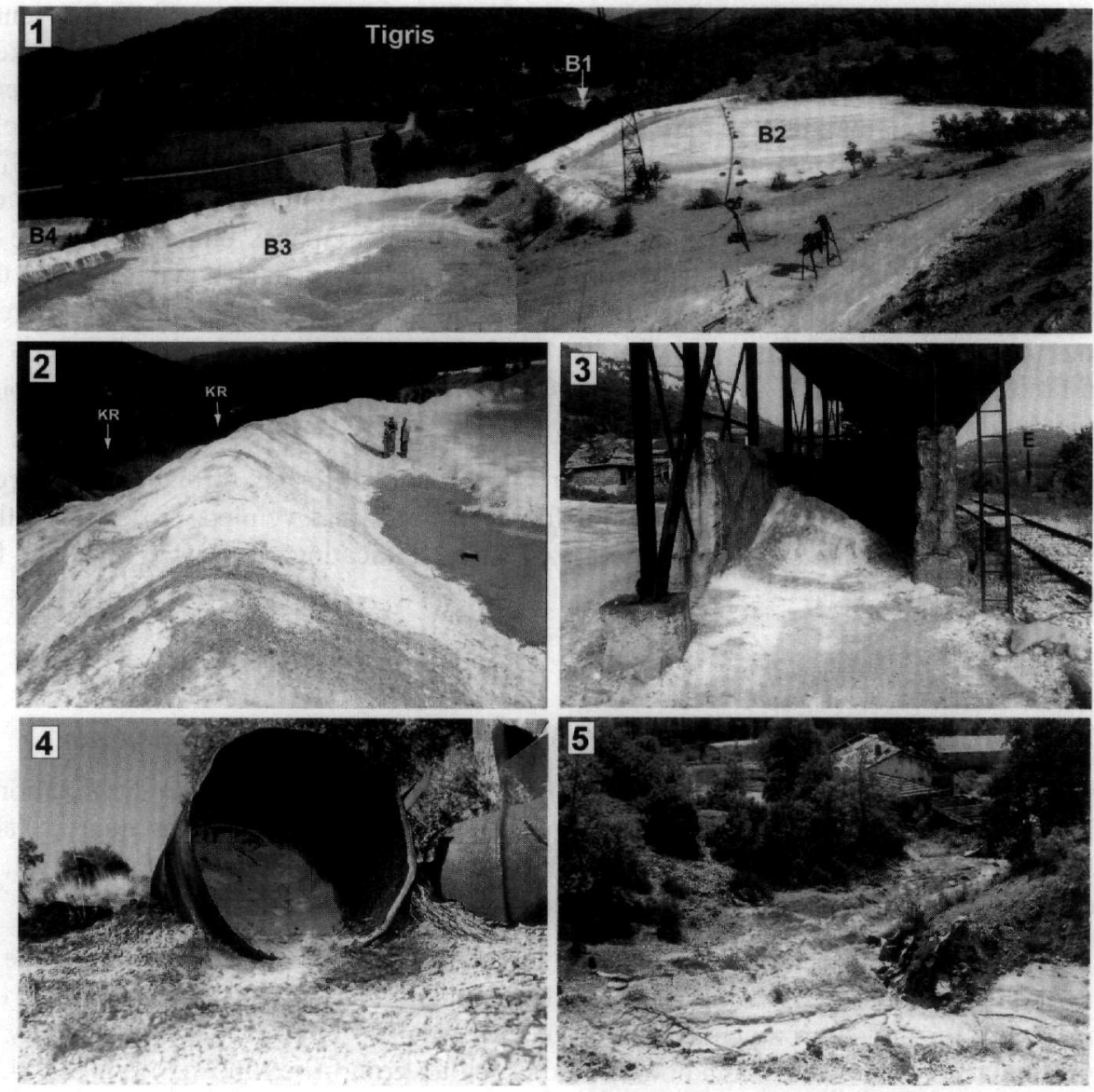

Figure 2 - Photographs from the area around the flotation plant in the Kirki area 1 . The tailing ponds (B1-B4) at the northeastern site. Tigris hill is in the background, 2. The tailing pond B3 with an intense white surface due to the formation of sulphate salts, part of which, evidently, are transported by the Kirkalon Stream (KR) and then by the Erini River, 3. Stocks of the ore-mineral concentrates at the flotation plant and the characteristic white areas, 4. An open destroyed barrel containing remains of an unknown chemical reagent, possibly cyanide solutions, 5 . Free transportation of the white coloured sulphate salts and the tailing ponds along channels at the eastern part of the plant towards the Erini River (in the background of the picture)

From the correlation of the various heavy metals (Fig. 3) in the tailing ponds and in the oremineral concentrates, it is evident that the As content correlates with $\mathrm{Pb}$ and especially with $\mathrm{Cu}$ content, since As is found mainly in the copper bearing minerals. In addition, a positive correlation is evident between $\mathrm{Cd}$ and $\mathrm{Zn}$ because they are both found in sphalerite and wurtzite. 


\subsection{The area around the flotation plant}

The area around the flotation plant is extremely contaminated because it is covered by scattered mining wastes and mineral concentrates, as well as by a large number of damaged barrels with various chemicals reagents, including sodium cyanide (Fig. 2). All these materials are exposed to the rain and the wind, and are dispersed throughout a wide area.

Table 1 - Concentrations (in ppm) of selected heavy metals from a total of 43 samples, in the sections of the six tailing ponds (B1-B6). T/1: lower content, T/2: higher content, T/3 average content. Su: higher content of the surface samples (depth of $0-2 \mathrm{~cm}$ )

\begin{tabular}{|c|c|c|c|c|c|c|c|}
\hline \multicolumn{2}{|c|}{ Tailing Pond } & \multirow{2}{*}{$\frac{\text { B1 }}{3,147}$} & \multirow{2}{*}{$\frac{\text { B2 }}{2,570}$} & \multirow{2}{*}{$\frac{\text { B3 }}{4,024}$} & \multirow{2}{*}{$\begin{array}{r}\text { B4 } \\
4,341\end{array}$} & \multirow{2}{*}{$\begin{array}{r}\text { B5 } \\
8,192\end{array}$} & \multirow{2}{*}{$\frac{\text { B6 }}{8,414}$} \\
\hline & $T / 1$ & & & & & & \\
\hline \multirow{3}{*}{$\mathrm{Pb}$} & $\mathrm{T} / 2$ & 3,325 & 5,791 & 7,950 & 12,496 & 14,599 & 10,136 \\
\hline & $T / 3$ & 3,230 & 4,321 & 5,845 & 6,572 & 10,382 & 9,173 \\
\hline & $\mathrm{Su}$ & 4,486 & 3,777 & 8,477 & 9,464 & 12,623 & 51,452 \\
\hline \multirow{4}{*}{$\mathrm{Zn}$} & $\mathrm{T} / 1$ & 7,786 & 3,495 & 8,861 & 802 & 10,342 & 10,434 \\
\hline & $\mathrm{T} / 2$ & 8,744 & 14,831 & 20,190 & 4,411 & 22,740 & 17,595 \\
\hline & $T / 3$ & 8,299 & 9,783 & 13,483 & 2,469 & 14,972 & 14,071 \\
\hline & $\mathrm{Su}$ & 7,007 & 42,959 & 57,833 & 23,826 & 6,777 & 53,390 \\
\hline \multirow{4}{*}{$\mathrm{Cu}$} & $\mathrm{T} / 1$ & 346 & 192 & 174 & 121 & 2,346 & 483 \\
\hline & $\mathrm{T} / 2$ & 694 & 262 & 388 & 609 & 3,895 & 556 \\
\hline & $T / 3$ & 467 & 195 & 267 & 252 & 2,940 & 509 \\
\hline & $\mathrm{Su}$ & 1,153 & 252 & 514 & 874 & 1,313 & 5,750 \\
\hline \multirow{4}{*}{ As } & $T / 1$ & 196 & 72 & 99 & 104 & 620 & 199 \\
\hline & $\mathrm{T} / 2$ & 262 & 133 & 139 & 193 & 944 & 255 \\
\hline & $T / 3$ & 222 & 106 & 124 & 139 & 733 & 223 \\
\hline & $\mathrm{Su}$ & 461 & 145 & 171 & 235 & 488 & 1,185 \\
\hline \multirow{4}{*}{$\mathrm{Cd}$} & $\bar{T} / 1$ & 90 & 28 & 77 & 5 & 71 & $\overline{80}$ \\
\hline & $\mathrm{T} / 2$ & 93 & 118 & 132 & 46 & 193 & 188 \\
\hline & $\mathrm{T} / 3$ & 91 & 81 & 106 & 22 & 123 & 124 \\
\hline & $\mathrm{Su}$ & 60 & 236 & 1,070 & 531 & 61 & 267 \\
\hline
\end{tabular}

In order to evaluate the impact of the various heavy metals in the sediments and soils, a series of standard, natural background values have been determined, after analysing uncontaminated sediments and soils of the studied area. Therefore, it would be possible to compare the chemical composition of the soils around the plant with the standard compositions and estimate the level of the contamination. These standard values are: $18 \mathrm{ppm}$ for $\mathrm{Pb}, 72 \mathrm{ppm}$ for $\mathrm{Zn}, 22 \mathrm{ppm}$ for $\mathrm{Cu}, 15$ ppm for As and $0.2 \mathrm{ppm}$ for $\mathrm{Cd}$.

The soils and the sediments in the vicinity of the flotation plant are also very highly contaminated (Table 3), although their chemical composition shows a large heavy metal fluctuation. Almost all the samples contain over $5,000 \mathrm{ppm} \mathrm{Pb}$ and $\mathrm{Zn}$. In places, the concentrations of $\mathrm{Pb}, \mathrm{Zn}, \mathrm{Cu}, \mathrm{As}$ and $\mathrm{Cd}$ reach up to $33,400 \mathrm{ppm}, 40,000 \mathrm{ppm}, 2,500 \mathrm{ppm}, 1,700 \mathrm{ppm}$ and $290 \mathrm{ppm}$, respectively. These values are respectively $1850,555,115,110$ and 1450 times higher than the standard background values. 


\subsection{The sediments of the Erini River}

The heavily contaminated tailing ponds and mineral concentrates, as well as the piles of unprocessed run-of-mine (ROM) material and the chemical reagents, sodium cyanide among them, constitute a long-term source of toxic metals and harmful compounds in the area of the flotation plant, being dangerous to public health. All these mining wastes are exposed to rain water, and thus the mobile elements are transported into the hydrologic network, mainly via the nearby small Krikalon Stream and then via the Erini River (Figs 1,2) which discharges to the Thracean Sea, east of Alexandroupolis.

A

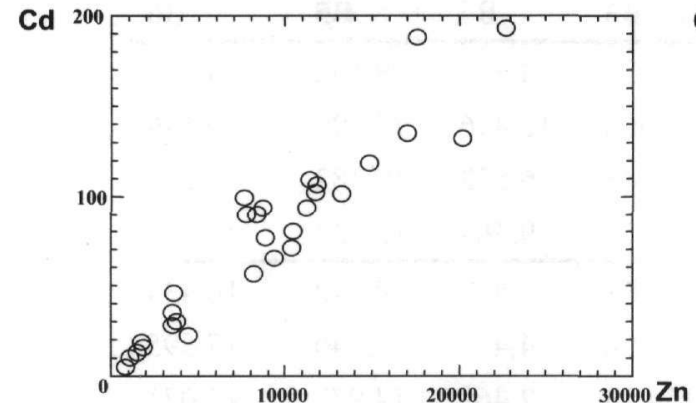

B

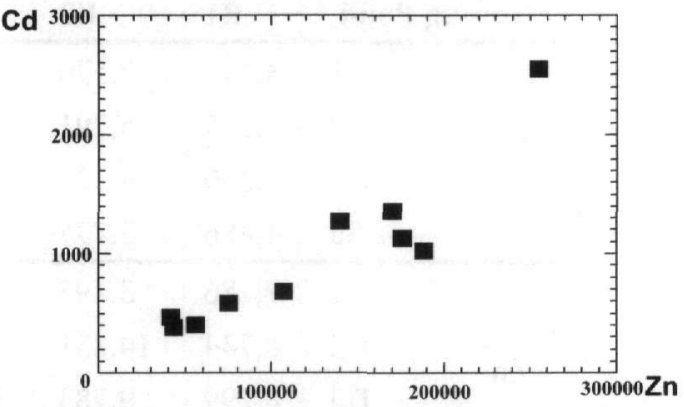

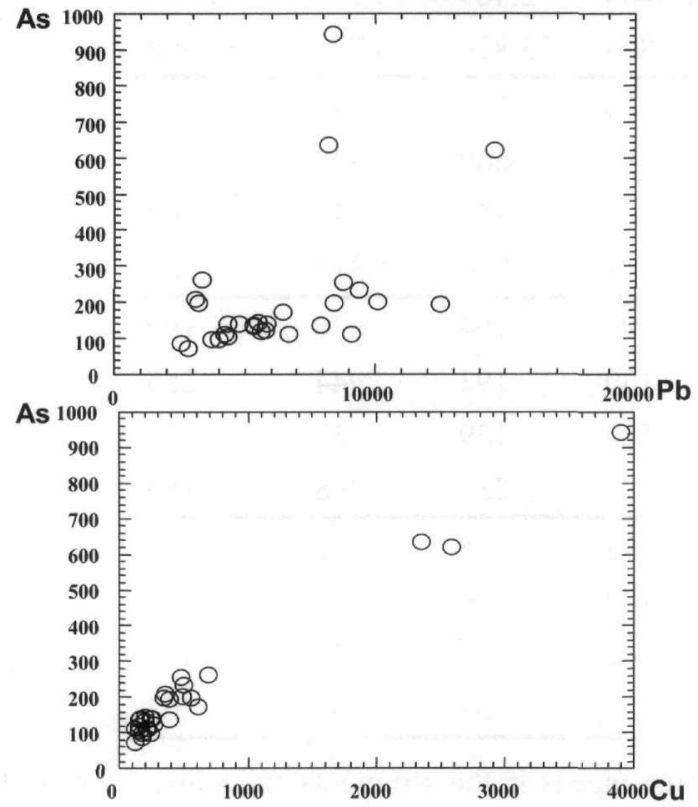

Figure 3 - Correlation of the heavy metals $\mathrm{Pb}, \mathrm{Zn}, \mathrm{Cu}, \mathrm{As}$ and $\mathrm{Cd}$, in the tailing ponds (A) and in the mineral concentrates $(B)$

The chemical analyses of the sediments along the Erini River have been presented by Arikas et al. (2004). The $\mathrm{Pb}$ concentrations reach 22,830 ppm, $\mathrm{Zn} \mathrm{6,210} \mathrm{ppm,} \mathrm{Cu} 760 \mathrm{ppm}$, As 1,700 ppm and $\mathrm{Cd} 51 \mathrm{ppm}$. These concentrations are respectively 1270, 85, 35, 115 and 255 times higher than the background values of the sediments. In the clay fraction of these samples the following heavy metals: $\mathrm{Pb}$ (up to $37,800 \mathrm{ppm}$ ), $\mathrm{Zn}$ (up to $21,550 \mathrm{ppm}$ ), $\mathrm{Cu}$ (up to $1,030 \mathrm{ppm}$ ) and $\mathrm{Cd}$ (up to 133 $\mathrm{ppm}$ ), are respectively $2100,300,47$ and 665 times higher than the standard background values. These particularly high values, within the clay fraction of the sediments, are very important because of the fact that they are transported very easily in the river waters. 
Table 2 - Chemical analyses (in ppm) of the scattered mining wastes and mineral concentrates. K1-K7: piles of concentrates in the plant, K8: piles of concentrates at the disposal site, 50 to $70 \mathrm{~m}$ from the plant, $\mathrm{K3a}$ and $\mathrm{K8a}$ : secondary minerals from the surface of the relative piles $\mathrm{K3}$ and $\mathrm{K8}$

\begin{tabular}{lcrrrrrrrr}
\hline Sample & Co & \multicolumn{1}{c}{ Mn } & \multicolumn{1}{c}{ Fe } & Pb & Zn & Cu & As & Cd & S \\
\hline K1 & 268 & 616 & 51,970 & 31,818 & 75,193 & 2,282 & 783 & 579 & 94,594 \\
K2 & 216 & 12,753 & 100,641 & 35,274 & 56,393 & 5,026 & 1,830 & 400 & 147,853 \\
K3 & 201 & 11,009 & 83,492 & 32,542 & 43,606 & 2,787 & 1,106 & 378 & 114,901 \\
K3a & 267 & 21,882 & 77,580 & 33,006 & 139,814 & 6,376 & 1,880 & 1,267 & 176,528 \\
K4 & 100 & 7,743 & 53,793 & 29,311 & 41,705 & 1,269 & 591 & $\square 65$ & 84,628 \\
K5 & 296 & 5,554 & 112,140 & 34,365 & 106,799 & 17,651 & 5,243 & 683 & 196,781 \\
K6 & 372 & 7,685 & 123,741 & 36,081 & 188,745 & 10,220 & 2,581 & 1,020 & 254,233 \\
K7 & 273 & 8,367 & 60,847 & 37,678 & 176,142 & 2,175 & 620 & 1,135 & 175,688 \\
K8 & 299 & 619 & 67,396 & 31,572 & 169,748 & 9,397 & 3,773 & 1,353 & 156,562 \\
K8a & 187 & 1,197 & 20,824 & 23,951 & 254,855 & 2,460 & 415 & 2,553 & 140,766 \\
\hline
\end{tabular}

Table 3 - Chemical analyses (in ppm) of samples from the soil and the surface sediments around the flotation plant. Samples of sections, $65 \mathrm{~cm}$ deep $\left(F 12^{*}: 0-15 \mathrm{~cm}\right.$, F13*: 15-25 cm, F14*: 25-45 cm and F15*: 45-65 cm)

\begin{tabular}{lrrrrr}
\hline Sample & \multicolumn{1}{c}{ Pb } & \multicolumn{1}{c}{ Zn } & \multicolumn{1}{c}{ Cu } & \multicolumn{1}{c}{ As } & \multicolumn{1}{c}{ Cd } \\
\hline F1 & 1,778 & 2,499 & 140 & 66 & 19 \\
F2 & 1,979 & 3,147 & 133 & 58 & 27 \\
F3 & 4,530 & 8,145 & 211 & 347 & 47 \\
F3a & 3,186 & 3,399 & 349 & 176 & 45 \\
F4 & 9,126 & 20,333 & 554 & 233 & 205 \\
F5 & 16,549 & 18,994 & 603 & 264 & 178 \\
F6 & 33,362 & 40,015 & 2,522 & 787 & 293 \\
F7 & 128 & 214 & 33 & 13 & 1,7 \\
F8 & 31,459 & 16,549 & 2,118 & 1,732 & 134 \\
F9 & 11,132 & 6,666 & 647 & 297 & 31 \\
F10 & 10,568 & 9,091 & 449 & 211 & 70 \\
F11 & 37,380 & 78,165 & 3,100 & 1,259 & 703 \\
F12* & 5,321 & 6,188 & 304 & 112 & 52 \\
F13* & 6,598 & 1,406 & 116 & 82 & 10 \\
F14* & 16,515 & 1,888 & 522 & 317 & 10 \\
F15* & 360 & 625 & 79 & 87 & 7,3 \\
F16 & 2,945 & 4,898 & 189 & 156 & 65 \\
F30 & 6,977 & 1,435 & 376 & 285 & 10 \\
\hline & & & & &
\end{tabular}


In the diagrams of figure $4 \mathrm{~A}$ it is shown that in both the loose sediments and the sediments of the $1^{\text {st }}$ terrace of Erini River, the correlations of $\mathrm{Zn}-\mathrm{Cd}, \mathrm{Pb}-\mathrm{As}$ and $\mathrm{Cu}-\mathrm{As}$ are positive as in the tailing ponds and the soils around the flotation plant. In contrast to the others, a few samples of the $1^{\text {st }}$ terrace show especially high concentrations of $\mathrm{Pb}$ and $\mathrm{As}$.

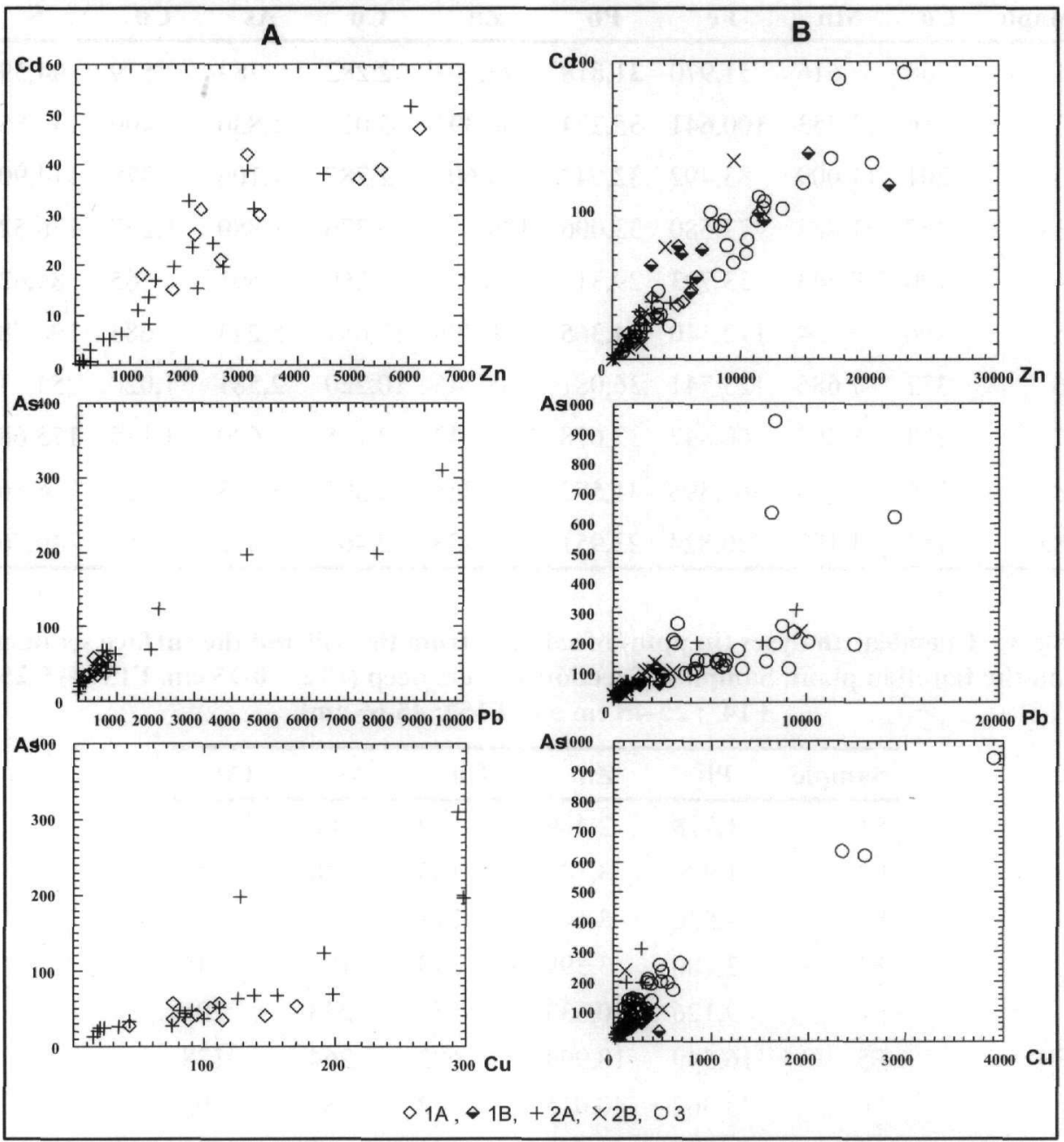

Figure 4 - Correlation of the heavy metals $\mathrm{Pb}, \mathrm{Zn}, \mathrm{Cu}$, As and $\mathrm{Cd}$, in the stream sediments (1A), in the sediments of the 1st terrace (2A) of the Erini River, their respective clay fractions $(1 \mathrm{~B}, 2 \mathrm{~B})$ and in the tailing ponds of the plant (3) for comparison

\section{Conclusions}

The present mineralogical-geochemical study demonstrates the extremely high risk to the environment and to public health, due to the heavy and toxic metal contamination of the area around the flotation plant and the Erini River near Kirki in the region of Evros. The tailing ponds, the soils and the sediments in the vicinity of the plant as well as the sediments of the river contain extremely high levels of $\mathrm{Pb}, \mathrm{Zn}, \mathrm{Cu}, \mathrm{As}$ and $\mathrm{Cd}$.

Field observations revealed that the "walls" of the six roughly-manufactured tailing ponds have been cracked, resulting in the discharge of the metal-bearing wastes and the sulfate salts in the 
stream of the adjacent Erini River. In addition, the mining area is saturated by scattered mining wastes and mineral concentrates, as well as by a large number of damaged barrels with various chemicals reagents, including sodium cyanide.

The most dangerous mineral species are the various sulfate salts which are the products of weathering of the mining wastes and which adsorb high quantities of $\mathrm{Pb}, \mathrm{Cu}$ and especially $\mathrm{S}, \mathrm{Zn}$ and $\mathrm{Cd}$, and as they are easily dissolved in water, they constitute the best carrier of heavy metals into the hydrologic system. In addition, due to the high sulfur content, they increase the acid drainage of the area. Facing the dangerous contamination of the hydrologic system from these toxic metals, it is important to check the existing wells close to the Erini River, which are used for the supply of drinking water in various areas within the Municipality of Alexandroupolis. A complete proposal for an effective remediation of the Kirki mining-waste site is planned for the future.

\section{Acknowledgments}

Special thanks are due to the University of Hamburg for the financial support of the present study. The author would also like to thank for their constructive cooperation the geologists N. Asfahani, A. Nowak and V. Watzl, as well as Dr. D. Goetz, from the Institut für Bodenkunde, Universität Hamburg, and Dr. V. Melfos from the Department of Mineralogy, Petrology and Economic Geology, Aristotle University of Thessaloniki. Special thanks are due to Dr P. Brady from the Sandia National Laboratories in New Mexico for carefully reviewing the manuscript and for his constructive comments and suggestions, resulting in significant improvement of this paper.

\section{References}

Arikas, K., Watzl, V., and Goetz, D., 2004. The environmental pollution from mining activities in Kirki, Alexandroupolis area, Bul. Geo. Soc. Greece, 36, 141-149.

Asfahani, N., Nowak, A., Arikas, K., and Goetz, D., 2005. Die Geochemie der Flotationsrückstände in der Umgebung der stillgelöegten $\mathrm{Pb}-\mathrm{Zn}$-Cu-Lagerstätte bei Kirki, Thrakien, Griechenland, Beih. zum Eur. Jour. Miner., 17, 7.

Astaras, T., Oikonomidis, D., Dimopoulos, G., Lambrinos, N., and Filippidis, A., 1997. Environmental monitoring of the Stratoni/Stratoniki area, Chalkidiki, Greece, using Landsat/TM digital images. In A. Spiteri (ed.), Remote Sensing '96, Rotterdam, Balkema, 145-149pp.

Christofides, G., Soldatos, T., Eleftheriadis, G., and Koroneos, A., 1998. Chemical and isotopic evidence for source contamination and crustal assimilation in the Hellenic Rhodope plutonic rocks, Acta Vulcanol., 10, 305-318.

Damigos, D. and Kaliampakos, D., 2006. The "battle of gold" under the light of green economics: a case study from Greece, Environ. Geol,. 50, 202-218.

Darlagiannis, D., Vavelidis, M., Arikas, K., Melfos, V., and Goetz, D., 2002. Environmental geochemica; study of the sediments in the Saporema and Filiouris rivers, Sapes-Xylagani area, Rhodope county, Thrace, Greece, Proc. of the 6th Greek Geographical Conference of the Greek Geographical Society, Thessaloniki, 445-452.

De Boorder, H., Spakman, W., White, S.H., and Wortel, M.J.R., 1998. Late Cenozoic mineralisation, orogenic collapse and slab detachment in the European Alpine Belt, Earth Planet. Sci. Lett., 164, 569-575.

Del Moro, A., Innocenti, F., Kyriakopoulos, C., Manetti, P., and Papadopoulos P., 1988. Tertiary granitoids from Thrace (Northern Greece): $\mathrm{Sr}$ isotopic and petrochemical data, $N$. $J b$. Miner. Abh., 159, 113-135. 
Dimou, E., 1993. A correlative mineralogical study of Achla Tarla and St Philippos mineralization, Kirki are (NE Greece), Bul. Geo. Soc. Greece, 28, 37-54.

Driesner, T., and Pintea, I., 1994. Constraints on the conditions of wurtzite formation at the Aghios Philippos Pb-Zn deposit, NE Greece. - Berichte der Deutschen Mineralogischen Gesellschaft, In European Journal Mineralogy, 6, No. 1, 54p.

Finitsi, A.V., Arikas, K., Goetz, D., Darlagiannis, D., Vavelidis, M., and Melfos, V., 2002. Geochemie von Böden und Bachsedimenten im epithermalen Gebiet von Sapes/Perama (Thrakien-Griechenland), Beih. zum Eur. Jour. Miner., 14, 43.

Karatasou, E., Vavelidis, M., Melfos, V., Koroneos, A., and Sklavounos, S., 2005. Heavy metal contamination of the Thermorema stream sediments at the Konos-Sapes district, Thrace, Greece. Proc. of the 2nd Symposium of the Committee of Economic Geology, Mineralogy and Geochemistry of the Geological Society of Greece, Thessaloniki, 133-142.

Kelepertsis, A., and Bibou, A., 1991. Heavy metal contamination of soils at old mining sites on Thasos island Greece, Environmental Geochemistry and Health, 13, 23-28.

Kitsopoulos, K., and Pavlidou, E., 2004. Exploitation of gold ores deposits. The press and the local society, environmental protection and concern. The case of Thrace region (Greece), Bul. Geo. Soc. Greece, 36, 350-359.

Michael, C., Constantinides D., Ashworth, K., Perdikatsis, V., and Demetriades, A., 1989. The Kirki vein polymetallic mineralization, NE Greece, Geologica Rhodopica, 1, 366-373.

Michailidis, K., Filippidis, A., Vavelidis, M., and Evangelou, E., 1989. Chemical composition of some ore minerals from the St. Philippos (Kirki) polymetallic deposits, Geologica Rhodopica, 1, 389-395.

Moëlo, Y., Oudin, E., Makovicky, E., Karup-Moller, S., Pillard, F., Bornuat, M., and Evangelou, E., 1985. La kirkiite, Pb10Bi3As3S19, une nouvelle espece minerale homologue de la jordanite, Bull. Mineral., 108, 667-677.

Mposkos, E.D., and Kostopoulos, D.K., 2001. Diamond, former coesite and supersilicic garnet in metasedimentary rocks from the Greek Rhodope: a new ultrahigh-pressure metamorphic province established, Earth Planet. Sci. Lett., 192, 497-506.

Papadopoulos, P., 1982. Geological map of Greece, Maronia sheet, scale 1:50.000, I.G.M.E., Athens.

Skarpelis, N., 1999. The Agios Filippos ore deposit, Kirki (Western Thrace). A base-metal part of a high-sulfidation epithermal system, Bul. Geo. Soc. Greece, 33, 51-60.

Skarpelis, N., and Triantafyllidis, S., 2004. Environmental impact from supergene alteration and exploitation of a high sulfidation epithermal type mineralisation (Kirki, NE Greece), Transactions of the Institution of Mining and Metallurgy. Section B: Applied Earth Science, $113,110-116$.

Vavelidis, M., Filippidis, A., Michailidis, K., and Evangelou, E., 1989. The polymetallic ore mineralization of the Kirki area, Alexandroupolis district, Northeastern Greece, Geologica Rhodopica, 1, 350-365.

Voudouris, P., Papavasiliou, C., and Melfos, V., 2005. Silver mineralogy of St Philippos deposit (NE Greece) and its relationship to a Te-bearing porphyry-Cu-Mo mineralization, Geochemistry, Mineralogy and Petrology, 43, 155-160.

Watzl, V., 1998. Untersuchung der von Bergbau und Erzaufbereitung verursachten Schwermetallbelastungen entlag des Flusses Erini (Thrakien, Griechenland), Diplomabeit, Mineralogisch-Petrographisches Institut, Universität Hamburg, 110p. 